\title{
Y21: CULTURE-LED REGENERATION IN TWENTY-FIRST CENTURY UK CITY REGIONS
}

\author{
KATY SHAW \\ Principal Lecturer, Leeds Beckett University UK.
}

\begin{abstract}
This paper is concerned with regions of cities, or 'City-Regions' and the capacity of culture as a mechanism of social development in the twenty-first century. It focusses on a case study research project 'Yorkshire 21' (Y21), funded by Leeds Beckett University, UK. This interdisciplinary project united academic researchers with local communities to enable small-scale, culture-led community regeneration projects in Yorkshire. It was born out of the university's mission to engage with and contribute to the well-being of the region, and to increase public engagement with academic research by establishing a conversation between scholars and members of the public. Following the exemplar of a series of creative writing community history workshops held as part of the project, the article examines a smallscale study of culture-led regeneration in a specific City-Region of the United Kingdom. Critically exploring community-led regeneration as a strategy based on recovery and valorization of local culture, the article proposes the centrality of community contributions to culture-led regeneration projects in contemporary UK City-Regions.

Keywords: city-region, community, community art, culture, regeneration, writing.
\end{abstract}

\section{MAPPING CITY-REGIONS}

The meaning of a 'city' carries new associations and implications in a post-millennial context. Manuel Castells reflects that 'futurologists' have long predicted 'the demise of the city, or at least cities as we have known them until now' [1]. This demise has been offered as a product of the rapid expansion of world financial markets over the past hundred years. These new conditions have led many sociologists and cultural critics to ask "what happens to place in a global economy?'[2]. In response, globalization scholars have proposed that the city is destined to play a decreasing role in contemporary interactions with finance and globally networked capitalism. Central to this de-territorialization lies an 'essential sameness' at the heart of globalized visions of the contemporary city [3]. As globalization expert Saskia Sassen argues, the 'dispersal capacities emerging with globalization and telecommunication [ . . . ] led many observers to assert that cities would become obsolete in the new economic context' [2]. In this 'borderless world' conventional geographic boundaries are less relevant and, as a result, the city loses its defining influence as a significant site [4].

Yet, in the twenty-first century, changes in the geography of the global economy have actually led to the rise of cities as zones of organizing influence. While the ongoing internationalization of economic relations may well mean less autonomy for a nation's cities, intense competition between cities remains and each enjoys unique social and political conditions and negotiates the growing interpenetration of local and global economies differently. Developments in the global economy are also presented in terms of territory, and the place remains 'central to the multiple circuits through which economic globalization is 
constituted' [5]. In practice, nations continue to be defined by cities of varying powers and geo-economic strength is still an important factor in influencing voting decisions and asset distribution. Investment is the lifeblood of a city, but proximity also creates capacity for growth and demand. Concentrating similar industries in a central space creates a capital pull on talent, drawing people who want to work in similar sectors into a single space. This magnetism also creates choice, since the wide availability of similar services in a city conspires to drive up standards and competition, and can increase productivity. Functioning as an effective gateway to industries that service the financial sector, city space now functions as a flywheel of national economies and a significant site of reinvention and sustainability.

The significant role played by cities in the twenty-first century means that their power and influence has also spread to the areas immediately surrounding these spaces. So-called 'CityRegions', areas of the city connected but not central to core urban sites, have enjoyed a renaissance in terms of focus and funding in recent years, In the United Kingdom, a new methodological approach to the definition of City-Regions has been developed over the past 30 years. The New Local Government Network proposed the creation of City-Regions as part of on-going reform efforts, while a report released by the IPPR's Centre for Cities suggested the creation of four large city-regions in Birmingham, Leeds, Liverpool and Greater Manchester. A framework for City-Regions (Working Paper 1 Mapping City-Regions) was produced by the office of the Deputy Prime Minister in 2006. The paper concluded that 'CityRegions essentially comprise a central urban core together with the relevant commuter hinterland. Their conceptual underpinning is clear: City-Regions are essentially functional definitions of the economic but also of the social 'reach' of cities'. However, the report also concluded by conceding that 'City-Region boundaries are essentially fuzzy and issue specific' [6]. Later, the UK Budget of 2007 cited the 'empowering all local authorities to promote economic development and neighbourhood renewal, with greater flexibility, stronger partnership working and cooperation from other agencies, and better incentives for achieving economic growth and for ensuring disadvantaged areas benefit from and contribute to economic development' and 'a differential approach that supports local authorities in all areas to work together more effectively where they so wish, for example through pooling resources, responsibilities and targets at the sub-regional level, and supporting the development of robust decision-making at this level'. For the purposes of this article, a 'City-Region' is understood as a site that is part of the city, yet geographically distanced from the urban core. Its ties to the central site are functional, and it is of a size considered operative for policy making and development strategies.

The Leeds City-Region is situated in Yorkshire, the biggest county in the United Kingdom. The biggest city in Yorkshire - Leeds - has a population of 3 million, 1.4 million employees and 109,000 businesses. The city is currently the largest City-Region economy outside London, generating $£ 60$ billion. This represents 5\% of England's total economic output and makes the economy of this City-Region larger than 9 other EU countries. Leeds is also the United Kingdom's largest manufacturing centre, with 133,000 jobs, the largest regional financial and professional services sector, and is home to 9 Higher Education institutes, including Leeds Beckett University, the Higher Education Institution (HEI) and main funder of this research.

\section{CULTURE-LED REGENERATION IN CITY-REGIONS}

The Oxford English Dictionary defines 'culture' as the 'customs behaviours characteristics of a social group a way of life or social environment, or a group of people subscribing or 
belonging to this action or practice'. The definition foregrounds the communal and participative aspects of culture, a shared encounter or approach to society or a union around a specific aim or aspiration. This participative approach is perhaps why culture is so often mobilized as part of regeneration strategies and policies aimed at City-Regions. Regeneration carries associations of recreation, rebirth and restoration and is often focused around a geographical area by the improvement of its economic and social conditions.

In the latter half of the twentieth century, these concepts were joined in an attempt to harness culture to enhance the regeneration of urban spaces and sites. Culture-led regeneration has historically been made intelligible through the modes of its operation - the actions, projects and products created from it. As Evans argues, culture-led regeneration positions 'culture as catalyst and engine of regeneration' and, therefore, to understand its aspirations requires a consultation of interrelated areas of urban policy, social policy, cultural policy and arts policy' [7]. Offering a new conceptual framework for culture in the context of de-industrial or underdeveloped spaces, the cultural aspect of regeneration formed a key concern of policy objectives throughout the 1990s in the United Kingdom.

These policies and resultant projects sought to humanise the architectural landscape of communities, making people feel invested in and connected to the buildings around them. The 1997 New Labour Government even authored an early discussion paper, Regeneration Programmes - The Way Forward, that offered a 'holistic' approach to regeneration, and promoted the "implementing the "bottom-up" approach' to regeneration to 'help promote "ownership" of regeneration activity in a local community' [8]. As a result, cultural regeneration projects such as the Bullring shopping centre in Birmingham and the Angel of the North sculpture in Gateshead were developed to create new structures that would generate a fresh aesthetics of old space, one that also significantly attempted to draw on the heritage of the place and connect it to the future.

However, in the new millennium, the economic challenges of the financial crash of 2008 created new challenges for the development of culture-led regeneration. While in the 2004 UNCHS report, The State of the World's Cities suggested that 'regeneration' was a global phenomena by the twenty-first century, one frequently adopted as an explicit urban policy by many of the world's major cities, not all major cities now have the budget or desire to engage in this work [9]. In the United Kingdom, a Conservative-majority coalition also made overt attempts to 'distance' itself from the policies and activities of the previous Labour government. Its new motto 'big society not big government', had the impact of unprecedented cuts in public expenditure in the United Kingdom in an apparent attempt to reduce the deficit [10].

As a result, much government action in the area of regeneration was reflective or summative rather than interventionist and large scale. Since 2015, under the Coalition Government, there have been 'new' funding streams and delivery mechanisms such as the Regional Growth Fund, Local Enterprise Partnerships and Enterprise Zones. However, these have primarily operated as instruments of economic development, rather than City-Region regeneration. By 2016 in Britain, culture-led regeneration has become a phenomenon largely left to the people, driven by the third sector rather than the public sector, and subject to reduced participation by the squeeze of governmental cutbacks and economic efficiencies.

\section{Y21: CULTURE-LED REGENERATION IN LEEDS CITY-REGIONS}

Against this social, cultural, political and economic backdrop, the 'Y21' project was launched in 2016. Funded by a major charitable donation by Leeds Beckett University, one of the biggest HEIs in Yorkshire, the project aimed to leverage and develop ongoing research across a 
group of academics working on approaches to socio-cultural regeneration and unite them with disadvantaged City-Region communities. Drawing on the lessons of past culture-led regeneration projects in the United Kingdom, and the work already established across this interdisciplinary field, the project aimed to explore the extent to which the City-Regions of Leeds could offer theoretical as well as spatial, economic and cultural frameworks within which new methodologies and multi-faceted theoretical paradigms could be used to explore the changed relationship between culture and regeneration in the new conditions of the post2008 context.

Through a distinct combination of academic-led public engagement events, the project sought to facilitate creative knowledge exchange opportunities and activities that mobilized and developed a range of new research partnerships. Its focus on Yorkshire City-Regions was born out of the university's mission to engage with and contribute to the well-being of the local region, and to increase public engagement with academic research by establishing conversations between scholars and members of the public. As such, the project sought to inject culture-led regeneration with some of the dynamism and scope that had defined projects of the previous century and to use the case study microcosm of a specific city-region to conduct a small-scale study of culture-led regeneration in a twenty-first century context.

To support the approach of the project, these interventions took the form of a series of workshops between academic staff and members of post-industrial Yorkshire City-Regions. Each workshop was held in partnership with local arts, cultural, heritage, or sporting organisations that shared the aim of engaging communities in debates about the role of their field in regenerating a place and its people in the twenty-first century. This paper focusses on a case study exemplar of one of the Y21 workshops that took the form of a series of community writing workshops hosted by academics and practicioners in New Wortley Community Centre. New Wortley Community Centre constituted a logical partnership for the Y21 project because it already enjoyed established links with Leeds Beckett University's 'Project Office', a not-for-profit architectural involved in designing the new community centre building. New Wortley is a City-Region of Leeds that, despite enjoying a close proximity to the city centre and core transport networks, suffers from a declining economic base caused by macro level changes from outside that have had a detrimentaleffect on the local community. It had previously been the subject of several central government regeneration programmes, but these had failed to solve, or often even to address the problems of these individual communities. In the context of a booming Leeds economy, the City-Region of New Worley lags distinctly behind the City itself in terms of housing, education, health and employment. The aim of the Y21 writing workshops was then to generate a range of new narratives that would tell the history of New Wortley and go on to be used by a graphic designer from the Project Office to create a mural for the walls of the top floor in the new community centre. The Y21 community history creative writing workshops encouraged participants to share their knowledge of local history, including anecdotal events that have become part of the area's story.

\section{REPRESENTING REGENERATION}

A mural was incorporated into the design of the new community centre building in New Wortley to empower residents to tell the story of their area. The word 'mural' originates from the Latin word 'murus', meaning 'wall'. Although mural art was a technique favoured by artists such as Leonardo Da Vinci and Michelangelo Buonarroti, the art of muralism mainly flourished during the 1920s, after the Mexican revolution as a tool of communication between the people and the powers that governed them. There is much critical writing on murals as a 
cultural representation in public art [11]. Mural paintings are cultural artefacts and as such they have a lifespan and a biography [12]. Historically associated with freedom of expression and social activism, murals are often employed as tools of social emancipation. In many places around the world, mural art is used to speak in the name of and depict communities, nations and cultures, as well as to represent an aesthetic element which helps them integrate into their environments (as iconically seen on the Berlin Wall in twentieth century Germany). Consequently, murals often exist as objects in a material world, but also that, as objects, their presence changes the physical context and the social nature of the environment in which they are painted [13].

The Y21 project upon this to establish a vision of the New Wortley community mural painting as a socially constructed artefact, one associated with longevity and legacy and involved in dynamic interaction with its local environment and one created by the creativity of local people. As a result, the creative writing community history workshops aimed to concentrate on creating the social bonds of solidarity and collective identity as a result of bringing neighbourhood residents together, providing a shared goal, and setting a common mood for the purpose of creating the mural. Fusing art and the environment with a political focus, murals often represent scenes of community life often across periods. Associated with community, a central focus of the New Wortley mural would be on moments in history when the people of New Wortley had come together to enact or encourage change.

The community writing workshops were advertised under the slogan: 'Bringing the community together to create a mural celebrating and sharing stories of the history and life in our area'. In the context of this research, the concept of a community is understood as a group of people who interact with one another, have a variety of ties that can be both psychological and social, and who collectively try to better their collective as well as individual circumstances [14]. Community also has a profound geographical dimension since individuals collectivize most often around issues or debates that exist in or relate to the area in which they live and/or work [15]. The geographic characteristics of place and, in particular, of the characteristics of the people and location, were all vital factors in understanding the community aspect of the centre and its mural creation and representations. To emphasise the significance of place - past, present and future - each workshop began with a tour of the new community centre site so that participants could see the space that the new mural would occupy.

The tour explained the purpose of the new community centre building, and the significance of the mural in tying together the past, present, and future of the community. Following the tour, the workshops began with a session on performativity and confidence building led by a RADA-trained dramatist. This encouraged participants to communicate and engage in a dialogue about themselves and their connections to the local area. Taking part in exercises that drew on drama and acting skills, participants mobilized memories through movement and developed story telling techniques through character building and hot seating. These sessions culminated in a self-scripted performance piece bringing to life a scene from New Wortley past, one set in the old cinema, another in the old shopping district. The second half of each workshop was directed by a local author and playwright who specialized in writing for children, community theatre and contemporary performance.

Working with objects from the area and memories of streets and place names, participants sketched out characters from the past - literally, by drawing around one another and populating their drawings with character-building post-it notes to build the layers of characterization informed by the past. This led to a session in which new community banners were created. 
The banners drew on the tradition of trade union banners of the past to create new images and mottos to represent New Wortley in the twenty-first century.

\section{LEARNING AND LEGACIES}

The writing workshops at New Wortley aimed to provide the community with a voice, a means of expression and the tools to develop curiosity, confidence and autonomy. Each workshop gathered memories and thoughts on the New Wortley community experience across the decades, but also encouraged the validation of the activity of writing as a productive pursuit. Presenting everyone as a writer, the workshops foregrounded equality of representation and feedback for community members as key to learning and communicating. At the end of each workshop, community participants gathered and shared their thoughts on the workshops with staff:

- 'It has made me think differently about the community and about writing'

- 'It has created new ideas - you only see world through your own eyes, but working as part of group and meeting new people has really opened up new communities'

- 'It's been fun! Really interesting and enlightening'

- 'I've worked with people I would have walked past in the street, its brought us together'

- 'I feel like our confidence has grown during the day, it's made us positive feeling and thinking differently'

- 'we have new insights into our community it's been educational and inspiring'

- 'It has made me more likely to attend future workshops'

- 'there was a real sense of connection to people and ideas, generations connecting with different ages'

- 'It's been great to have the freedom to think and speak in public without being judged'

- 'It was completely different to what was I expected - writing at school made me feel stupid, but this was really inclusive and has built my confidence through getting everyone to contribute, you can't just hide away'

As Fromm argues, art is central to transforming 'an atomistic to a communitarian society', offering a distinct and important setting for social interaction [16]. The form of the mural in community art is also significant since it speaks to both the setting and the creation of the art within the public realm [17]. Defined by its collaborative nature in the creative process, the Y21 workshops encouraged members engage at the fundamental level of informing the new community centre mural design through their writing, so they in turn felt responsible and accountable for the art work produced at the end of the project. With an aim to bring pride and change to communities and individuals, as well as to transform the negative perception of people and places in City-Regions, the project foregrounded community involvement in the whole process from inception to design creation and application.

The cooperative and enriching group experiences in the workshop contexts resulted in solidarity and increased social bonds, new relationships and improved communication, new friendships and reduced isolation and adult-youth interactions and facilitated relationship building between individuals of different ethnic backgrounds. Importantly, it also provided support and a space to exchange common concerns and community issues, a chance for participants to explore their own identities as well as that of their community and thereby expand their definitions of themselves [18]. Co-authoring a collective response to the issues under discussion appeared to deepen a sense of social cohesion and, through creating a piece of 
community narrative and art, members found 'a way of speaking as an expanded community... [one that] takes shape when diverse people, speaking as who and not what they are, come together in both speech and action to constitute something in common among themselves' [19]. By examining ways of expressing and articulating a common culture and concerns it awakened memories of the past as well as gave residents the chance to reflect on the identity of the place today and what narratives they wanted to pass on to the next generation of people who will live there and use the new community centre building.

The indicators of success for this project were not just limited to the production and reception of the community mural. Like many cultural-led regeneration projects, Y21 created more long-term benefits and developments than originally anticipated in the research brief. As a result of the enthusiasm and appetite for community writing workshops demonstrated by end-users during the project, New Wortley Community centre worked with academics to apply for Arts Council England (ACE) and local council funding to begin regular scheduled community writing classes at the new centre building. The project also led to an annual spinoff literary festival - Word Up West Leeds - that enjoyed its inaugural date in 2016 and can now be found on Twitter. The project also went on to form a case study for the formation of the new cultural strategy underpinning Leeds' Capital of Culture bid for 2023, and was used as an example of effective investment and transformation as part of the - winning - application to establish a new health and well-being hub attached to the new community centre in 2018. The new hub will be designed by the university Project Office and host writing classes as part of its ongoing well-being programme and bid to become a Well-Being Hub as part of the UK National Health Service network in 2018. The outcomes and feedback from the project suggest that not only were the original objectives for delivering a community-led mural delivered, but that additional tangible long-term benefits for education, well-being and participation in the community were also enabled.

\section{COMMUNITY, CULTURE, REGENERATION: WRITING SHARED FUTURES}

The outcomes of the Y21 community writing project suggest that any successful model of culture-led regeneration must be founded upon the acknowledgement that locality is critical to understanding the ability of different communities to undertake regeneration activities. As Vickery reflects, for most 'regeneration projects the problem of 'inclusion' is chronic' [20]. As a response to the challenge of inequality between the inhabitants of cities and CityRegions, collective participation in the Y21 workshops positioned participants not just as an audience for the culture or arts being generated, but as part of a shared project of authorship by the people for the people - that enabled the mural to become a symbolic point of public congregation.

Despite the limitations of the relatively short duration and narrow geographical reach of this project - limitations that were themselves the result of funding constraints - the findings of this case study are nevertheless significant because they suggest ways in which culture-led regeneration can be used as a tool for social change and development in a twenty-first century City-Region community. It also suggests that strategically investing in events and opportunities for small-scale engagement between the academy and local communities can lead to more sustainable practices and development opportunities. On a wider level, the project points towards the transformative possibilities of writing, suggesting ways in which the act of writing can function as a significant part of the culture-led regeneration process, offering positive validation for individuals sharing their writing with others, making sense of seemingly chaotic experiences or making conscious the meaning they assign to narratives about 
the past, present and future [21]. Because the workshops were set apart from daily life at a specific time and place dedicated to this activity, participants put aside their roles and status in the everyday world. In this way, they stepped beyond their normal roles and began to reconstruct their stories in new ways [22]. In this way, culture-led regeneration demonstrated its potential to change not only the fortunes of a society, but also to shape the lives of the individuals living in a City-Region.

Major challenges to the future of this research lie in the austerity measures currently facing communities, civic councils, charities and HEIs across the United Kingdom. New Wortley remains a community under threat - while it currently has the most heavily used community centre in the city, it is nevertheless subject to longer-term uncertainty regarding how long funding will continue, and whether a stable population will remain in the City-Region to make use of the centre. Clearly, the success of some of the outcomes of the Y21 project - such as creative writing classes and an annual literary festival - depend on funding to ensure the continuation and development of this work in the longer term. A reduction in funding streams could potentially stymie expertise from external and inventive approaches that seek to leverage and create resources for local communities to sustain them through the austerity period. Yet, as this case study demonstrates, opportunities to regenerate City-Regions and their communities through an engagement with culture is not impossible, but actually present a viable and successful way of navigating and negotiating 'the policy landscape they now face' [23]. As such, this paper concludes with a call for a more longitudinal analysis of the impact of community art and creative writing workshops on making lasting impacts on communities, and more funding opportunities for such work to be undertaken.

\section{REFERENCES}

[1] Castells, M., The Rise of the Network Society, Blackwell Publishing: New York, p. 462, 2000.

[2] Sassen, S., Analytic borderlands: economy and culture in the global city. In Companion to the City, eds. G. Bridge \& S. Watson, Wiley: London, p. 234, 2000.

[3] McGrew, A., A global society? In Modernity and Its Futures, eds. S. Hall, D. Held \& T. McGrew, Polity: London, pp. 61-102, p. 73, 1992.

[4] Ohmae, K., Managing in a borderless world. Harvard Business Review, 67(3), p. 153, 1989.

[5] Sassen, S., The Global City, London, New York, Tokyo, Princeton University Press: Princeton NJ, p. 267, 2000.

[6] Office of the Deputy Prime Minister UK, A Framework for City-Regions Working Paper 1: Mapping City-Regions, available at: http://www.ncl.ac.uk/curds/publications/pdf/ AFrameworkforCityRegionsWorkingPaper1PDF3314Kb_id11635961.pdf, 108, 2006.

[7] Evans, G., Measure for measure: evaluating the evidence of culture's contribution to regeneration. Urban Studies, 42(5-6), pp. 959-983, 2005.

http://dx.doi.org/10.1080/00420980500107102

[8] DETR, Regeneration Programmes: The Way Forward, London, Department of Environment, Transport and the Regions/ Stationery Office, 21, 1997.

[9] UN_HABITAT, State of the World's Cities 2004/2005 - Globalization and Urban Culture, available at: http://mirror.unhabitat.org/pmss/listItemDetails.aspx?publication $\mathrm{ID}=1163 \&$ AspxAutoDetectCookieSupport=1, 2004. 
276 Urban Regeneration and Sustainability

[10] Conservative Party, The Conservative Party Manifesto 2015, available at: https://www. bond.org.uk/data/files/Blog/ConservativeManifesto2015.pdf, 2015.

[11] Hodder, R., Redefining a southern city's heritage: Historic preservation planning, public art, and race in Richmond, Virginia. Journal of Urban Affairs, 21(4), pp. 437-453, 1999.

http://dx.doi.org/10.1111/0735-2166.00030

[12] Koyptoff, I., The cultural biography of things: commoditization as a process. In The Social Life of Things, ed. A. Appadurai, Cambridge University Press: Cambridge, 1986. http://dx.doi.org/10.1017/CBO9780511819582.004

[13] Jarman, N., Painting Landscapes: the place of murals in the symbolic construction of urban space. In Symbols in Northern Ireland, Institute of Irish Studies, ed. A. Buckley, The Queen's University of Belfast: Belfast, 1998.

[14] Christenson, J., Fendley, K. \& Robinson, J., Community development, In Community Development in Perspective, eds. J. Christenson \& J. Robinson. Ames, Iowa State University: Iowa, pp. 3-25, 1989.

[15] Friedmann, J., Empowerment: The Politics of Alternative Development, Blackwell: Cambridge, MA, 1992.

[16] Fromm, E., The Sane Society, Holt, Rinehart \& Winston: New York, p. 303, 1955.

[17] Raven, A., Art in the Public Interest, Da Capo Press: New York, 1993.

[18] Weitz, J., Coming Up Taller: Arts and Humanities Programs for Children and Youth at Risk, President's Committee on the Arts and the Humanities: Washington, 1996.

[19] Greene, M., Releasing the Imagination: Essays on Education, the Arts, and Social Change, Jossey-Bass: San Francisco, p. 155, 1995.

[20] Vickery, J., The Emergence of Culture-led Regeneration: A Policy Concept and its Discontents, available at: http://wrap.warwick.ac.uk/36991/1/WRAP_Vickery_ccps. paper9.pdf, 2007.

[21] Ochs, E. \& Capps, L., Living Narrative: Creating Lives in Everyday Storytelling, Harvard University Press: Cambridge, 2001.

[22] Turner, V., The Anthropology of Performance, PAJ Publications: New York, 1986.

[23] Broughton, K., Where next for neighbourhood regeneration in England? two years on local economy November/December 2013. Local Economy, 28(7-8), pp. 817-827, 2013. http://dx.doi.org/10.1177/0269094213496610

[24] McKay, M.A., National Soul: Canadian Mural Painting, 1860s-1930s, McGill-Queens University Press: Kingston, 2002.

[25] Boothroyd, P. \& Davis, H., Community economic development: three approaches. Journal of Planning Education and Research, 12, pp. 230-240, 1993. http://dx.doi.org/10.1177/0739456X9301200307

[26] Burns, T.R. \& Engdahl, E., The social construction of consciousness, part 2: individual selves, self-awareness, and reflectivity. Journal of Consciousness Studies, 5(2), pp. 166-184, 1998. 